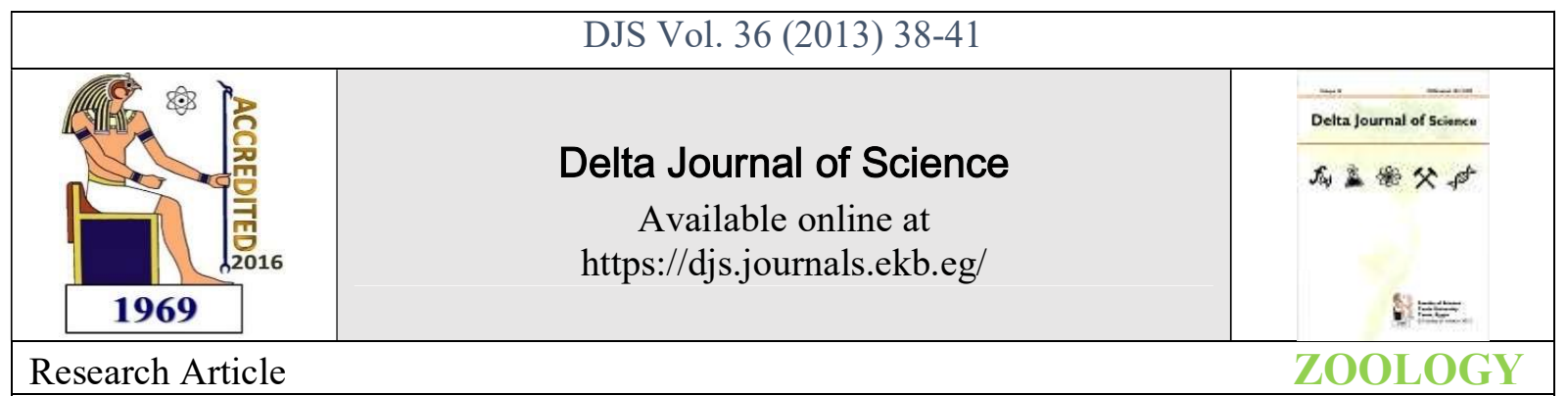

\title{
Honey Bee tissues as a biomarker for Environmental pollution with heavy metals.
}

\author{
Yahya Al-Naggar, Mohamed H. Mona, El-Saied Naiem and Amal I. Seif. \\ Department of Zoology, Faculty of Science, Tanta University, Tanta, Egypt.
}

\begin{abstract}
The purpose of this study is to verify the importance of the body surface and tissues of foraging honey bee Apis mellifera as bioaccumulator of heavy metals that can therefore, be included in biomonitoring programmes of heavy metals in terrestrial ecosystems. The presence of five representative heavy metals (copper, zinc, cadmium, lead and iron) was investigated in honey bee tissues (mid gut, hind gut and fat body), body surface and wings using proton induced X-ray emission method. X-ray spectrums of mid gut and fat body of forager bees demonstrated small peaks for $\mathrm{Cd}, \mathrm{Pb}, \mathrm{Fe}$ and $\mathrm{Ni}$ compared to the control. Moreover, slightly larger peaks for $\mathrm{Cu}$ and Zn were noticed in the X-ray spectrums of whole honey bee mid gut, hind gut and fat body than those of the control. Forager honey bee body surface showed small peaks for $\mathrm{Cu}$ and $\mathrm{Pb}$ compared to the control. Similarly, small peaks for $\mathrm{Cd}, \mathrm{Pb}$ and $\mathrm{Ni}$ were noticed in the $\mathrm{X}$-ray spectrums of wings and hind gut of the forager honey bee compared to control.
\end{abstract}

\section{Keywords:}

\section{Honey bee workers, Biomarker, Heavy metals, $X$-ray spectral analysis}

\section{INTRODUCTION}

Biosphere pollution by chemicals and heavy metals is accelerated dramatically during the last few decades due to mining, smelting, manufacturing, use of agricultural fertilizers, pesticides, municipal wastes, traffic emissions, industrial effluents and industrial chemicals etc. On the other hand, human exposure to hazardous toxic heavy metals in the environment is difficult to assess. Most available methods utilize equipments or laboratory analyses which consume a lot of time. So we are in urgent need to fast and in situ methods (Meissner et al., 2004). One of the possible alternative approaches to this problem is the use of biological indicators. An indicator may be used for biomonitoring at many levels of organization, ranging from sub organism (i.e., gene, cell and tissue) and organism to population, community, and even ecosystem levels (Niemi and McDonald 2004).

The use of insects as bio-indicators in terrestrial and aquatic ecosystems is of great interest in ecotoxicological studies (Braeckman et al., 1999; Braeckman and Raes 1999). A great variety of insects can accumulate toxic environmental compounds in their tissues (Introna et al., 2001). In many parts of the world, attempts were made to use bees to assay the degree of environment pollution (Muszynska 1995). Moreover, many investigators commend upon the possibility to use bees to monitor the purity of the environment (Roman 1997, 2000). However, programs for their use as bioindicator do not seem to have been instituted in Egypt.
Accordingly, the aim of the present study is to verify the effectiveness of honey bee worker and its tissues (mid gut, hind gut and fat body) as bioaccumulator of heavy metals.

\section{Materials and methods}

\section{Collection of honey bees}

Honeybees were collected from a private apiary in Egypt at Kafr El-Sheikh governorate during spring honey harvest 2010. This selected apiary was within agricultural area located near the highway connecting Tanta city and Kafr El Sheikh characterized by motor vehicle circulation. The apiary contains 120 bee hives belonging to a beekeeper. This apiary was specifically constructed without any metal part in order to avoid the risk of contamination of the assayed materials. Forager honey bee workers were carefully brushed directly into a disposable polyethylene bags from three bee hives after fuming by smoker to calm the bees. The bees were collected from the honey combs located on the farthest side walls of the hive. These were normally old bees probably more exposed to airborne pollution. After the collecting trip, all samples were frozen at $-4 \mathrm{oC}$ in the laboratory (Fakhimzadeh and Lodenius 2000).

Mean while, the control worker honey bees group was obtained from a laboratory colony. This group was brought from the same apiary during spring as pupae and maintained at $36{ }^{\circ} \mathrm{C}$ and $60 \mathrm{Rh}$ in the incubator till complete development. Honey bee workers of ( $0-48 \mathrm{hr})$ were then sampled. 
Proton-induced X-ray emission spectroscopy

Dissection and preparation of honey bee tissues were carried out as described by Raes et al. (1985). The alimentary canal was removed from the abdomen by gently pulling the last abdominal segment and the Malpighian tubules were carefully cleared away. Mid gut, hind gut and fat body were fixed in 70 $\%$ ethanol.

The samples were allowed to air dry for 1-2 hour before analysis, resulting in a total specimen thickness of $<1.0 \mathrm{~mm}$. Samples were taped over numbered openings in an aluminum rotating wheel, and placed in a scattering chamber which was then pumped to a vacuum of $<10-6$ Torr. The samples were excited with a $7 \mathrm{~mm}, 15-20 \mathrm{nA}$ proton beam. The induced Xrays from the specimen were collected by a $\mathrm{Si}(\mathrm{Li})$ energy dispersive detector, and the spectra fed into a Nuclear Data 6600 Data Acquisition System for analysis. Precautions were taken to capture back-scattered electrons and transmitted protons by placing electrified apertures in front of and behind the samples. The size and placement of the beam were checked by visualizing the beam on a zinc sulphide film. The analyses were performed by scanning electron Microscope (JSM- 5300) at Electron microscopic unit - faculty of scienceAlexandria University.

\section{Results}

\section{Proton-induced X-ray emission (PIXE):}

Energy dispersive X-ray spectra of air-dried tissues of honey bee workers showed small peaks for $\mathrm{Al}, \mathrm{P}$ and $\mathrm{S}$ in all investigated honey forager bee tissues as well as in the control. The X-ray spectra of forager bee body surface showed small peaks for $\mathrm{Cu}$ and $\mathrm{Pb}$ compared to the control (Figs 1A\&1B). Similarly, small peaks for $\mathrm{Cd}, \mathrm{Pb}$ and $\mathrm{Ni}$ were noticed in the X-ray spectra of the wing and hind gut of the forager honey bee compared to the control (Figs 1E, 1F, 1I \&1J).

The X-ray spectra of mid gut and fat body of forager bee demonstrated small peaks for $\mathrm{Cd}, \mathrm{Pb}, \mathrm{Fe}$ and $\mathrm{Ni}$ compared to the control (Figs 1C, 1D, 1G \&1H). Moreover, slightly larger peaks for $\mathrm{Cu}$ and $\mathrm{Zn}$ were noticed in the X-ray spectra of the wing of the forager bee and their dissected tissues (mid gut, hind gut and fat body) than those of the control (Figs 1C, 1D, $1 \mathrm{E}, 1 \mathrm{~F}, 1 \mathrm{G}, 1 \mathrm{H}, 1 \mathrm{I} \& 1 \mathrm{~J})$.

\section{Discussion}

Trace elements in insects were found on the surface of their chitinous exoskeleton or incorporated into their body tissues (Hare 1992). Internal or external localization of trace elements in honey bee foragers can determine their potential to reflect contamination. External heavy metal contamination of external surface and wings of honey bee workers collected compared to the laboratory colony control may result from deposition from environmental contamination mainly due to anthropogenic processes. External contamination can result in higher concentration of $\mathrm{Cu}$ and $\mathrm{Zn}$ in the wing lead us to suggest that the pollutants were scattered throughout the atmosphere and they were impregnated or deposited on the bee surface. The lead in the urban and industrial areas was found in higher quantities inside the bee than on the bee surface. The results for lead could indicate that persistent contamination induces high absorption of pollutants by inhalation or ingestion into bee bodies during foraging.

Although we have no precise information about the age of the forager honey bees used in the present experiment, the bee age could be 25-45 day. Indeed, the presence of even small peaks for $\mathrm{Cd}$ and $\mathrm{Pb}$ in all tissues of forager honey may reflect the environmental pollution with these metals and verify the possibility of using them as biomarkers for environmental pollution with heavy metals.

Honey bees are exposed to condition of the environment in which they live, since its existence is directly associated with the natural environment. Therefore, if it functions in polluted environment, plant products used by honey bee may also be contaminated and as a result also a part of these pollutants will accumulate in it as revealed by Accorti et al., (1990); Balestra et al., (1992); Roman (1997, 2003). The additional reason for the increase of the content of toxic elements in bee is partial removal of pollutants into honey crop during its processing with the formation of honey, the effect of which a part of them accumulates in bees' organs (Jedruszuk 1987; Roman and Demenczuk 2003). Several authors came to the same conclusion. Van Rinsvelt et al. (1973) investigated the application of ion induced X-ray fluorescence to study the relative concentration of several major and trace elements present in the tissues of 9 species of adult and immature insects. Results of the qualitative analyses indicated that $\mathrm{K}, \mathrm{Ca}, \mathrm{Ti}, \mathrm{V}, \mathrm{Mn}, \mathrm{Fe}, \mathrm{Ni}, \mathrm{Cu}, \mathrm{Zn}, \mathrm{Pb}, \mathrm{Rb}$, and $\mathrm{Sr}$ could easily be identified from a single spectrum. Levy et al. (1979) analyzed adult and immature stages of Solenopsis richteri Forel and S. geminata for total body concentration of 16 major and trace elements using ion induced $\mathrm{X}$-ray fluorescence. They indicated that $\mathrm{P}, \mathrm{S}, \mathrm{Cl}, \mathrm{K}, \mathrm{Ca}, \mathrm{Ni}, \mathrm{Cr}, \mathrm{Ti}$, $\mathrm{Fe}, \mathrm{Cu}, \mathrm{Zn}, \mathrm{Mn}, \mathrm{Pb}, \mathrm{Sr}, \mathrm{Mo}$, and $\mathrm{Rb}$ could be detected in ash samples of major and minor workers, pupae, and larvae.

Krantzberg and Stokes (1990) found that, $\mathrm{Pb}, \mathrm{Fe}, \mathrm{Cd}$, $\mathrm{Cu}, \mathrm{Ni}, \mathrm{Zn}$, and occasionally, $\mathrm{Al}$ accumulated in the mid gut and anal papillae of chironomids, with the greatest frequency of detection occurring in the mid gut of larvae collected from the more heavily contaminated site. Furthermore, the present results are in a good agreement with Kuterbach et al. (1982), Kuterbach and Walcott (1986a), Kuterbach and Walcott (1986b). They reported accumulated iron rich granules in the fat body of adult honeybees. Similarly, Raes et al. (1989) indicated that, not only in the fat cells but also in the columnar cells of the mid gut of honey bee workers, iron-rich granules in both cell types were formed within the cisternae of the rough endoplasmic reticulum.

\section{Conclusion}

The presence of even small peaks for $\mathrm{Cd}$ and $\mathrm{Pb}$ in whole honey bee workers collected and their tissues (mid gut, hind gut and fat body) compared to the control, may indicate the ability of honey bee workers to accumulate these toxic metals in their tissues. Moreover, it may emphasize the possibility of using whole honey bee workers and their tissues (mid gut, hind gut and fat body) as biomarkers for environmental pollution with heavy metals.

\section{References}

Accorti M, Guardini R, Modi G, and Persano-Oddo L. (1990) Urban pollution and honey bees. Apicoltura 6: $43-55$

Balestra V, Celli G, and Porrini C. (1992) Bees, honey, larvae and pollen in biomonitoring of atmospheric pollution. Aerobiologia 8 (1): 122 - 126.

Braeckman B, and Raes H. (1999) The ultrastructural effect and subcellular localization of mercuric chloride and methylmercuric chloride in insect cells (Aedes albopictus C6/36). Tissue Cell 31:223-232

Braeckman B, Brys K, Rzeznik U, and Raes H. (1999) Cadmium pathology in an insect cell line: ultrastructural and biochemical effects. Tissue Cell 31: 45-53. 
Bunting H. (1949) The histochemical detection of iron in tissues. Stain Technology 24:109-115.

Fakhimzadeh K, and Lodenius M. (2000) Honey, pollen and bees as indicator of metal pollution. Acta Universitatis Carolinae Enviromentalica 14:13-20

Hare L. (1992) Aquatic insects and trace metals: Bioavailability, bioaccumulation and toxicity. Critical Reviews in Toxicology 23:327-369.

Introna F, Campobasso C P, and Goff M L. (2001) Entomotoxicology. Forensic Science International 120: 4247.

Jedruszuk A. (1987) Bees and bee products as environmental pollution indicator. National Veterinary medicine 6:352 - 356 .

Krantzberg G, and Stokes P M. (1990) Metal and tissues distribution in larvae of Chironomus with reference to X-ray microprobe analysis. Archives of Environmental Contamination and Toxicology 19: 84-93.

Kuterbach D A, and Walcott B. (1986a) Iron containing cells in the honeybee (Apis mellfiera). I. Adult morphology and physiology. Journal of Experimental Biology 126: 375-387

Kuterbach D A, and Walcott B. (1986b) Iron containing cells in the honeybee (Apis mellfiera). accumulation during development. Journal of Experimental Biology 126: 389-401

Kuterbach D A, Walcott B, Reeder R J, and Frankel R B. (1982) Iron-containing cells in the honeybee (Apis mellitera). Science 218:695-697.

Levy R, Cromroy H L, and Rinsvelt H A. (1979) Relative comparisons in major and trace elements between adult and immature stages of two species of fire ants. Florida Entomology 62: (3) 260-266.

Meissner K T, Lippert A, Wokaun D, and Guenther D. (2004) "Analysis of trace metals in comparison of laser-induced breakdown spectroscopy with LA-ICP-MS" Thin Solid Films, 453-454, pp. 316-322.

Muszynska J. (1995). Bee products as indicators of environmental contamination. Med. Wet. 51 (8): 457-458.

Niemi G J and McDonald M E. (2004) Application of ecological indicators. Annual Review of Ecology, Evolution, and Systematics 35:89-111.

Raes H, Bohyn W, De Rycke P H, and Jacobs F. (1989) Membrane- bound iron-rich granules in fat cells and midgut cells of the adult honey bee (Apis mellifera L.). Apidologie 20:327-337.

Raes H, Jacobs F, and Mastyn E. (1985) A preliminary qualitative and quantitative study of the microscopic structure of the dorsal fat body in adult honey bees (Apis mellifera), including a technique for the preparation of whole sections. Apidologie 16:275-290.

Roman A, and Demenczuk D. (2003) Reducing the contents of selected trace elements in raw honey during its processing into honey by the honeybee. Scientific Papers Agricultural University. H. Kollataja in Krakow, Gardening, Issue 25:1919-1930.
Roman A. (1997) Bees and bee products as bioindicator of environmental contamination in the area of influence of industry of copper (LGOM) and cement-lime (Opole). AR Scientific Papers of Wroclaw, Animal Husbandry 323: 175 196

Roman A. (2000) Comparative studies of $\mathrm{Cd}, \mathrm{Pb}$ and $\mathrm{Zn}$ in honey, propolis and wax from regions of Wałbrzych and Glogowski. Pszczeln. Zesz. Nauk supplement No 1:76-77

Roman A. (2003) Influence of the toxicology of honey on the level of accumulation of selected trace elements in the body honeybee (Apis mellifera L.) Acta Agrophysica (2): 295-300.

Roman A. Bees and their products as pollution bioindicator in the copper (LGOM) and lime-cement (Opole) industry areas. Scientific Exercise Books of Agricultural University in Wroctaw 323: 175 - 196

Van Rinsvelt H A, Duerkes R, Levy R, and Cromroy H L. (1973) Major and trace element detection in insects by Ion Induced X-ray Fluorescence. Florida Entomology 56: 286290. 

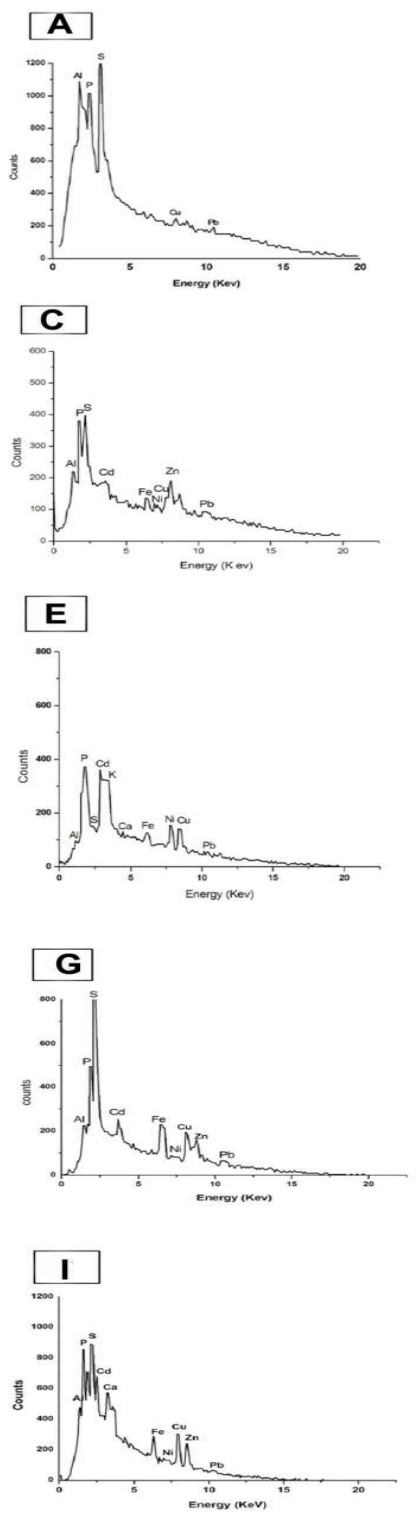
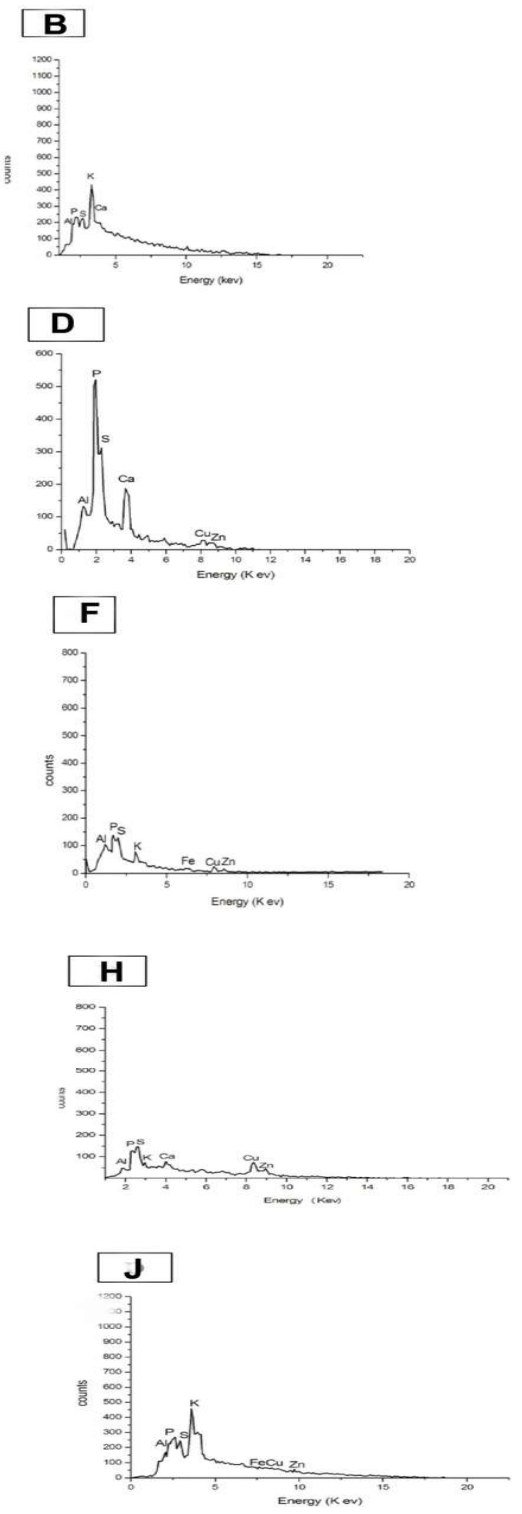

Figure 1: Energy-dispersive X- ray spectra of heavy metals in Apis mellifera workers. A\&B: Energydispersive X-ray spectra of heavy metals of bee body surface of forager bees and laboratory-reared 
control. C\&D: In mid gut of forager bees and laboratory-reared control. E\&F: In hind gut of forager bees and laboratory-reared control. G\&H: In fat body of forager bees and laboratory-reared control. I\&J: In bee wing of forager bee and laboratory-reared control. 